\title{
Pioneers in Neurosciences: The Sherrington Era
}

\author{
William Gibson \\ Chancellor, University of Victoria \\ Victoria, British Columbia
}

In considering what one person has unified and promoted the area of neuroscience beyond all others' contributions, I have come to the view that Sir Charles Sherrington and his many students share this great honor. As his last student at Oxford 1 find myse If in the privileged position of being the "terminal bouton" - if not the "final common pathway" in recounting the history of this great little man with the sparkling eye, a chuckle in his voice as he posed stupendous questions, and an abiding faith in the progressive understanding of the nervous system which awaited only the wise application of grey matter for its elucidation.

From my arrival in Oxford in 1935 until Sir Charles' death in 1952 at the age of 95,1 had the wonderful privilege of chatting with him, or exchanging letters with him on the history of what we call today the broad field of neuroscience. He claimed that his "Iast illegal act" as Wayneflete Professor of Physiology at Oxford" was to appoint me as a demonstrator in histology, which was at that time, in Britain, usually taught within departments in physiology.

I soon learned that Sherrington was no mean histologist. In fact he had begun life as a pathologist, soon developing a curiosity in gross and microscopic anatomy that later made him a superior physiologist.

Let me begin at the beginning of Sherrington's career therefore, bringing together the strands - his students - with which he wove a tapestry of neuroscience unsurpassed. As a medical undergraduate, at Cambridge, Charles Sherrington accompanied the professor of physiology, John Newport Langley, to London in 1881 for the International Medical Congress, where, as William Osler said, "the sight of above 3,000 medical men from all parts of the world, drawn together for one common purpose, and animated by one spirit was enough to quicken the pulse and to arouse enthusiasm to a high pitch." One can imagine the quickening of the pulse of Sherrington, the medical student, as he saw and heard such giants as Lister of antisepsis fame, Hughlings Jackson the great localizer of cerebral function, Charcot the famed French neuroscientist, Sir James Paget after whom several diseases are named, Huxley, "Darwin's bulldog", Louis Pasteur, Rudolph Virchow the Berlin Pathologist who gave us the word "neuroglia", John Billings who gave us the National Library of Medicine, Robert Koch the tubercle bacillus demonstrator, Brown-Séquard and Ferrier the great neurologists. To some these giants may mean little, a century later, but they are the researchers on whose shoulders we all stand as we "search and study out the secret of nature by way of experiment" as William Harvey said 400 years ago.

With eyes half-way out of their sockets Sherrington witnessed a demonstration, by Goltz of Strasbourg, of a dog which had had a large part of one cerebral hemisphere removed, with little or no apparent deficit in its movements. Goltz told the congress that he had thus proved that there was no cerebral localization of function whatever. Whereupon, David Ferrier, an outstanding experimentalist and clinician showed a monkey

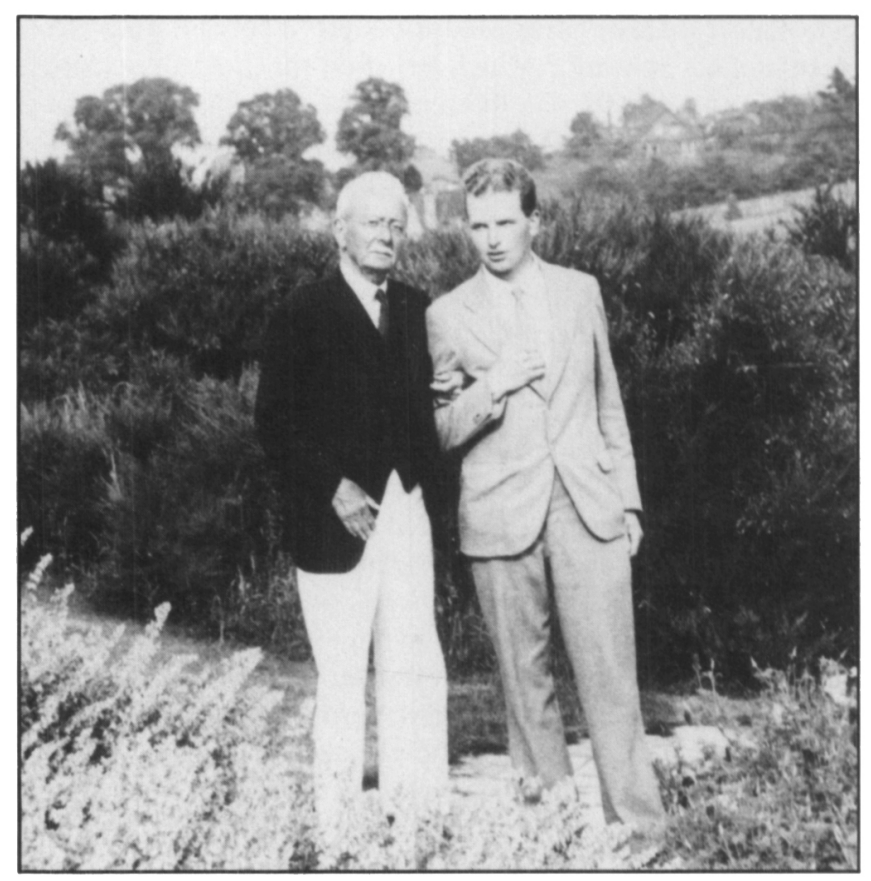

Figure 1 - The author with Sherrington in his garden in Ipswich. Suffolk in 1937 
from which he and Professor Yeo, the King's College, London, physiologist, had removed a cortical area 7 months before. The monkey hobbled across the stage, demonstrating great weakness in the limbs opposite to that of the ablation. Charcot cried out "C'est un malade!".

To emphasize the point even further Ferrier showed another monkey with bilaterial removal of the hearing area of the cortex dating back ten weeks. The monkey was oblivious to the explosion of a percussion cap beside it, "proving" that the cortical ablations had produced total deafness.

Pandemonium ruled as Goltz shouted: "When one attempts to grasp the truth at the height of these babbles, the edifice crumbles ... I will prove beyond the shadow of a doubt that Ferrier's theory is completely false." Finally it was decided that a committee would be struck, to report on the brain of the dog shown by Goltz. Sherrington on returning to Cambridge was given by Professor Langley the task of studying the spinal degeneration which followed the decortication in Goltz's dog. Three years later, the youthful Sherrington joined with Langley to describe their findings on the famous dog. Thus Sherrington reported his first research in the Journal of Physiology which was owned and edited by Langley. This paper was followed by 319 others during Sherrington's long life!

After receiving his Medical degree at Cambridge, Sherrington boldly set off for Goltz's laboratory in Strasbourg for nine months' study of cerebral function. He noted the changes in the life of the Alsatian natives as the German presence became established as a result of the Franco-Prussian War.

Soon, however, Sherrington joined his friend C.S. Roy, the youthful professor of pathology at Cambridge in the study of an allegedly successful vaccine against cholera in Spain. Along with Graham Brown they sought to investigate cases in a number of affected areas near Madrid, notably Toledo. There they were stoned by a mob which believed the English scientists were responsible for the disease in the first place. In distant Zaragossa the young Santiago Ramón y Cajal was studying the same cholera epidemic, but there was no meeting between them. A year later Sherrington, the pathologist, was hot on the trail of cholera in Italy. With his early training in the classics he revelled in the early printed volumes which could then be bought there, thus beginning a collecting and donating habit which eventually made him the greatest donor of incunabula to the British Museum of all time.

Then followed a sojourn in the laboratory of the great German pathologist Rudolf Virchow in Berlin - the father of cellular pathology and the man who coined the word "neuroglia" - or "nerve glue". Virchow had been banished in 1849 to Wurzburg for seven years because of his liberal political views. He mixed these with his neuropathology by announcing to his students that the King of Prussia had softening of the brain; his father had hardening of the brain, and the grandson no brain at all.

Sherrington thus found Virchow restored to his post in Berlin and with enormous political acclaim as the sworn enemy of the Prussian "dictator" Otto von Bismarck. As chairman of the finance committee of the Reichstag Virchow was able, years later, to deny Bismarck the huge navy which he sought. So Charles Sherrington witnessed the struggle between brass-booted Prussian aristocracy and the concerned German democrats which ended, for the latter group, when Hitler and his friends burned the Reichstag and silenced all dissent in 1933. Through two world wars Sherrington recalled his student days with the great Virchow, and came to the aid of refugee scientists who managed to escape to Britain.

Returning to England our new neuropathologist found a physiology lectureship open at St. Thomas' Hospital Medical School across the Thames from the Houses of Parliament. Soon he was immersed in investigating the pathological changes in the spinal cord and medulla in a case of locomotor ataxia, and in one where death had followed a cerebral haemorrhage. Gradually his interest in pathology dove-tailed with his student interests in the physiology of the cerebral cortex. It would be fair to say that neurohistology became the middle ground of his interest at this period, and I must stress the fact that throughout his long life Sherrington was a master of histological technique. In his four years as a very junior member of faculty at St. Thomas' Hospital he produced a dozen papers, laying the groundwork for his immense future contribution to the fundamentals of modern neurology. Strangely, his contribution with C.S. Roy, to our knowledge of the cerebral blood circulation, is only now being recognized by authorities such as Seymour Kety as the basic truth in this much disputed field. The St. Thomas' Hospital period came to an end in 1891 with the appointment of Sherrington as Physician-Superintendent of an animal shelter endowed by a Dublin lawyer named Thomas Brown who, 37 years earlier, had left his fortune for an institution "investigating, studying and without charge . . . endeavouring to cure maladies, distemper and injuries any Quadrupeds or Birds useful to Man may be found subject to." Five lectures per year, in English, were required, and the University of London had supervisory powers. Brown hoped that diseased animals would be used to promote science.

Sherrington's four predecessors had been Sir John Burdon Sanderson whose names were given years later to J.B.S. Haldane; W.S. Greenfield, the father of the distinguished future neuropathologist of Queen Square J. Godwin Greenfield; C.S. Roy of the Spanish cholera expedition, and Sir Victor Horsley, the father of Victorian brain surgery. Horsley vacated the post at the Brown Institution in order to run for Parliament on an anti-smoking, anti-drinking platform, unsuccessfully.

Sherrington immediately saw the potential of this subsidized animal laboratory and in his first four years there published 20 papers. They concentrated on the course of various fibre tracts in the spinal cord, on the explication of spinal reflexes, and on epilepsy.

Recently elected to the Royal Society he was soon pressed into editorial work for its Transactions. He dismissed as "detrimental to the quality and character of the Transactions" a paper which contained an historical introduction "going back to Galen and the cartilagenous fishes". He was later to review the paper of the Canadian researcher A.B. Macallum "on the distribution of chlorides in nerve cells and fibres". Sherrington's own papers were models of useful erudition, and he proved that the "muscle spindles" demonstrated by his friend Ruffini were sensory in nature. He plunged into the histology of these annulospiral nerve endings himself, staining them with methylene blue.

Attracted as he was by cerebral localization as a field for study Sherrington wisely concluded that it could be understood only after the less complicated circuitry of the nervous system had been mastered. He therefore turned to the elucidation of spinal reflexes, their interaction, and predicated a "final common pathway". As a first class neurohistologist he built upon 
the revolutionary findings of a native genius beyond the Pyrennes - Santiago Ramón y Cajal. In isolation, Cajal had produced preparations of nervous tissue using Golgi silver stains which electrified the microscopic anatomists of the age. The impenetrable forest containing billions of individual nerve cells began to yield to Cajal's infinite capacity for hard work. He was so impoverished in ill-paid university posts that he would have to put a dozen sections of mouse brain on one glass slide. He sent his first papers, published in local dailies to the crowned heads of Europe. Some of them reached Sherrington who was then Foreign Secretary of the Royal Society in London. It was not long before Cajal was invited by Sherrington, on behalf of the Society, to give the Croonian Lectures, and in 1894 Cajal set

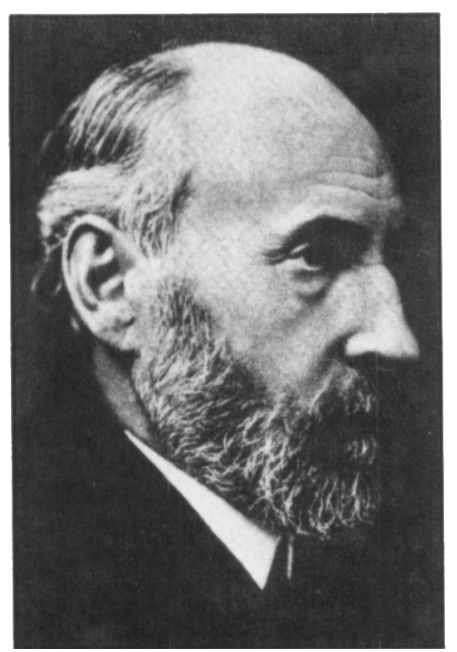

Figure 2 - Dr. SantiagoRamóny Cajal

out with his precious slides to convert the British group. Though the word "neurology" was coined by Thomas Willis - Christopher Wren's teacher at Oxford - as long ago as the 17th Century - the pursuit of the fine texture of the nervous system was not very swift.

Now, in 1894 however, Cajal as Sherrington's guest had dropped a bomb. No one could imagine the complexity which Cajal's preparations showed. In provincial fashion he sought only "believers" who had looked down the microscope set up at the Royal Society in Burlington House. You can imagine the traffic jam that ensued. Sherrington foreseeing this, had prepared lantern slides of some of the specimens but Cajal refused to show them! Sherrington gave two of them to me at Oxford saying "I could not show them. Perhaps you can some day."

At the risk of losing the thread of the Cajal - Sherrington symbiosis let me add that Cajal's visit to Sherrington was accompanied by some slightly bizarre episodes. Every morning Cajal would air all the bedclothes over the balcony of the Sherrington house. He was despatched by train to Cambridge by Sherrington's wife whose husband had had to go by an earlier train for meetings at his college, Gonville and Caius by name. Cajal arrived safely but a little earlier than expected, so that he missed Sherrington at the Cambridge station - which it is said still looks like a public convenience. Instead of waiting for his host, Cajal wandered off, entirely entranced by the beauty of the colleges, while Sherrington sought for him in vain. Finally the police were called, as graduation time approached, and it was found that Cajal had been arrested as he had been obstructing traffic in the narrow streets while making sketches of the hallowed towers!
The important thing for us is, of course, the neurohistological basis which Cajal was laying for the neurophysiological interpretation of Sherrington. Both saw the "boutons terminaux" as the points of contact between a transmitting axon and receiving cell body next in line. With the aid of the gifted Belgian histologist, van Gehuchten, the "law of the dynamic polarization of the neuron" was launched. Sherrington supplied not only the physiological proof but some of the histology as well.

Clearly, a new word was needed to identify the area of contact - not continuity - between nerve cells in a circuit, and this deficiency Sherrington supplied. He consulted his Cambridge colleague Verral, who like Sherrington was a classical scholar. In what Auden has called "that nicely balanced Cambridge view" Verral suggested that "syndesm" or "synapse" might convey the desired meaning. Sherrington chose "synapse" because the adjective "synaptic" sounded better than "syndesmic".

Shortly, Sherrington was made professor of physiology in Liverpool. He hit his stride in research on reflexes. A rising star in this slowly developing field, he was invited to give the Croonian Lectures at the Royal Society; he chose as his title "The Mammalian Spinal Cord as an Organ of Reflex Action". In this setting, so much simpler than the cerebral cortex, he mined pure gold. He showed that several reflexes could interact, and, importantly, that inhibition was an active, not a passive state.

Thus the building blocks of the nervous system - the neurons - were characterized in both form and function by a young professor who looked like a classical scholar, which he was, but who had a most fertile imagination in things neurological. During his Liverpool years Sherrington had important visitors to his laboratory, including Harvey Cushing from Johns Hopkins University - whom I consider to be the father of modern neurosurgery. Before he knew it, he was helping Sherrington to map the electrically excitable cerebral cortex of higher primates. His skill as an artist was applied to this interesting adventure. but, most of all, Cushing's bibliomania struck a sympathetic chord in Sherrington. They corresponded concerning the collecting of rare medical books for the rest of their lives.

The American psychologist Robert Sessions Woodworth came from Columbia University for a protracted period and could hardly tear himself away from the world's leading neurophysiological - not to say neuropsychological - laboratory. Sherrington had visited North America in 1897 with Lord Lister and other members of the British Association for the Advancement of Science, proceeding to the furthest western city, Victoria, British Columbia. In 1903 he again visited Toronto, spoke on "Medical Science" and shared the honors with Sir William Osler the Canadian who made Johns Hopkins such a great medical centre. I assume that one of the Yale University professors present at the Toronto proceedings, together with Harvey Cushing, one of Yale's best known graduates, arranged to have Sherrington invited to give the Silliman Lectures there in 1904.

From these lectures came Sherrington's classic, "The Integrative Action of the Nervous System" which did for the nervous system what William Harvey's 72-page De Motu Cordis did for the circulatory system. Some idea of its importance can be gathered from the fact that it has been reprinted seven times since it appeared in 1906. The first edition has become a rare book, it is so eagerly sought after. 
Sherrington's ten lectures began with the nerve cell and ended with "physiological and psychical signs of neural activity". In the bibliography he quoted more than 300 publications, beginning with Descarte's works of 1648 and 1662. His concluding statement reads as follows:

The cerebrum . . . comes . . to be the organ par excellence for the readjustment and the perfecting of the nervous reactions of the animal as a whole, so as to improve and extend their suitability to, and advantage over, the environment. These adjustments, though not transmitted to the offspring, yet in higher animals form the most potent internal condition for enabling the species to maintain and increase in sum its dominance over the environment in which it is immersed. A certain measure of such dominance is its ancestral heritage; on this is based its innate right to success in the competition for existence. But the factors and the elements of that competition change in detail as the history of the earth proceeds. The creature has to be partially readjusted if it is to hold its own in the struggle. Only by continual modification of its ancestral powers to suit the present can it fulfil that which its destiny, if it is to succeed, requires from it as its life's purpose, namely the extension of its dominance over its environment. For this conquest its cerebrum is its best weapon. It is then around the cerebrum, its physiological and psychological attributes, that the main interest of biology must ultimately turn.

The students at Yale gave him a testimonial dinner. How times have changed! The Yale Alumni Weekly quoted an auditor of the lectures, "I understood the whole of it. Everyone knows how a dog scratches himself when a flea bites him." The year previously the same graduate had listened to a physicist read his Silliman Lectures, and recorded his impression thus: "I understood all the words; but I sat there for an hour, and I did not know a thing the man had said." In contrast, the lucidity of Sherrington's prose was such that the uninitiated could follow the argument, based on facts discovered. The impact of The Integrative Action was enormous. F.M.R. Walshe, one of the greatest clinical neurologists of modern times wrote to Sherrington in the dark days of World War II: "I look to it, to turn my mind sometimes from the grim world that surrounds us all now, and to renew in its pages some of the delight that I found when (Professor) Bayliss gave me a copy ... some thirty years ago when I was a student. Such as my work has been since, what I got from the book has been the best part."' I venture to emphasize this point because it is not generally realized by some "internists" that Sherrington established the physiological background against which neurologists today carry out the clinical examination of patients. True, some clinicians seemed to live to put their names on obscure "reflex" jerks of various parts of the body - like a bunch of botanists bestowing their names on flowers encountered in a jungle.

As you can imagine, Sherrington's laboratory in Liverpool became Mecca for students of the nervous system. Alfred Frölich, of the adiposogenital syndrome was an early pupil. Alexander Forbes of Harvard was one of those who trooped ashore at Liverpool from the then active trans-Atlantic ships.

The echo of The Integrative Action had not died when the University of Toronto invited Sherrington to assume the chair in physiology. Dejected by an intransigent dean of medicine who sought to chop Sherrington's curricular offerings by onehalf, our hero wrote a letter of acceptance on a Friday night and posted it. He could not sleep for the two nights following, and on Sunday gained access to all the trans-Atlantic mail in the Liverpool post office, found his letter and tore it up. Soon Columbia University attempted to lure him away, but they too failed. Thus, if Sherrington would not cross the Atlantic, students would have to come to him in Liverpool. The Canadian,
Fred Miller did so, and on returning became professor of physiology at the University of Western Ontario. It was he who employed Banting as a demonstrator in physiology at London, Ontario. Banting's first paper was written with Miller on cerebellar physiology!

Thereafter the Liverpool laboratory became a "power house" from which reflex physiology issued as from a fountain. American pupils came to study over the years - such as Grayson McCouch, Stanley Cobb and Henry Viets. Reciprocal inhibition, reflex stepping and standing, the scratch reflex, and localization of cortical function in primates continued to expand. The preserved brains of twenty-five of Sherrington's animals were handed to the Australian neuro-pathologist Alfred Campbell whose laboratory was located at Rainhill Asylum not far from Liverpool. In a colossal undertaking Campbell stained alternate sections, laboriously cut, one for fibres and the other for cells. The result was what $I$ consider to be the finest atlas of cerebral constituents ever produced. Even Lorente de No, Cajal's most critical pupil, regarded Campbell as "the only cytoarchitectonist who has described facts and only facts." Typically, Sherrington persuaded the Royal Society to make a grant to permit its publication by the Cambridge University Press in 1905.

The highly productive and happy Liverpool period came to a sudden end when the Wayneflete Professorship of Physiology at Oxford became vacant upon the sudden death of Francis Gotch. Sir William Osler, the Ontario-born Regius (or Royal) Professor of Medicine quickly convened the committee of electors and Sherrington was their unanimous choice. He entered Oxford early in 1914 and was soon to be "surrounded" by Rhodes scholars such as Wilder Penfield who, twenty years later, founded the Montreal Neurological Institute; Wilburt Davison who founded the Duke University Medical Faculty; Emil Holman who became professor of surgery at Stanford University; and C.F. Krige from South Africa. These students soon became Sir William Osler's "guinea pigs", since, the world war had erupted, and the anti-typhoid vaccine produced at Oxford needed urgently to be tested before it was sent off to Gallipoli and other theatres of war.

Physiology classes were very small with the war on, and smaller still when Penfield, enlisted in the American Red Cross hospital in France for service between terms, and Davison was, according to Osler, put in charge of all bed-pans in the Balkans. However, the kymographic recordings by these students were treasured by Sherrington and were used as illustrations in his laboratory manual "Mammalian Physiology" which he published at the end of the war. One continental reviewer faulted the book because it contained illustrations by Englishmen only. The illustrations were, in fact, copies of the recordings made by Sherrington's American undergraduates! Two inborn characteristics of Sherrington came to the fore early in his Oxford years - his book-collecting and his poetry - the latter being diffidently kept under wraps for years. With the war at its height, but with Sherrington convinced that the submarine menace was over, he sent a very precious volume to the University of British Columbia which had just emerged, in 1915, from being a McGill College. To the first president of U.B.C., Dr. Frank Wesbrook his companion of Cambridge days, he sent his copy of Bidloo's "Anatomy" published in Holland in 1685. This great copper-plate volume had belonged to the famous British architect Nicholas Hawksmoor, one of Christopher 
Wren's pupils, whose London churches and Oxford colleges are masterpieces. Sherrington had purchased the volume as a Cambridge student and was now sending it to help found a new library in Vancouver. To add to its significance, if additions were needed, he had his friends who visited his laboratory in 1914-15 autograph it: Sir William Osler, John McCrae of Flanders Fields, Gowland Hopkins the co-discoverer of the vitamins, Walter Raleigh the critic and Arthur Thomson the professor of anatomy at Oxford.

This magnificent volume, together with William Harvey's manuscript notes, published by the Royal College of Physicians of London and sent to President Wesbrook by Osler, were the beginning of the world-famous collections in the history of medicine and science to be found today at the Woodward Biomedical Library in Vancouver.

On the poetry front Sherrington was actively writing his haunting verses about war-time Oxford: "Now in the cloister few the feet that roam," and "Spring Term 1914" which appeared in his volume of poems in 1925 and is reprinted below.

\section{Oxford}

The night is fallen and still thou speakst to me, what though with one voice sole, with accents many, Tongued turret and tongued stream, tracked pasture fenny, and cloister spirit trod, and centuried tree and, bondsmen loosed in Time's tranquillity, thy bell dischargèd hours. If wharfage any thine 'tis where Age shall, nursing late his penny, smile at long last to hand him Charon's fee.

And now, below, through shadows starr'd, a boat steals by me laden with singing and young laughter, and, higher, a wide-flung casement casts afloat pulses of waltz the which white robes sway after; vowed Priest of Beauty, these thy shrines among, thou kneelst with old folk, thou that dancest with young.

In the aftermath of war Sherrington busied himself not only in his laboratory but also in aiding scientist-refugees. He was suggested by Harvey Cushing as a possible successor to Osler as Regius Professor of Medicine - in effect the dean of the medical school - but that would have wasted his valuable time and talents. However, by unanimous resolution of the Council of the Royal Society he was named its president for the years 1920-1925. This entailed frequent morning or evening train trips to London, sometimes both in one day!

Nevertheless the Rhodes scholars kept coming in profusion: John Fulton from Harvard and Howard Florey from Adelaide, South Australia. Both were post-graduate students living at Magdalen, Sherrington's lovely college on the river. Succeeding Wilder Penfield at Merton College was the New Englander, Marshall Fulton. The next wave brought Eccles from Australia and Denny-Brown from New Zealand, to be followed in the 1930 's by the brothers Hoff from Seattle, Ruch from Oregon, Magladery from Toronto, Pfaffmann from Brown University, David Lloyd and yours truly from McGill. This is not to suggest that Sherrington lacked native British disciples for they numbered among them the distinguished Bazett, Liddell, Creed, Sybil Cooper and Whitteridge.

Eccles has written in detail of the halcyon days of neurophysiology in which he and Ragnar Granit participated - in what can only be called spartan quarters. I can attest to the hyperactivity of the laboratory preceding the mammalian classes when a large number of white-coated laboratory technicians anaesthetized the cats in a small ante-room. There the boys sang raucously Salvation Army hymns which they had learned years

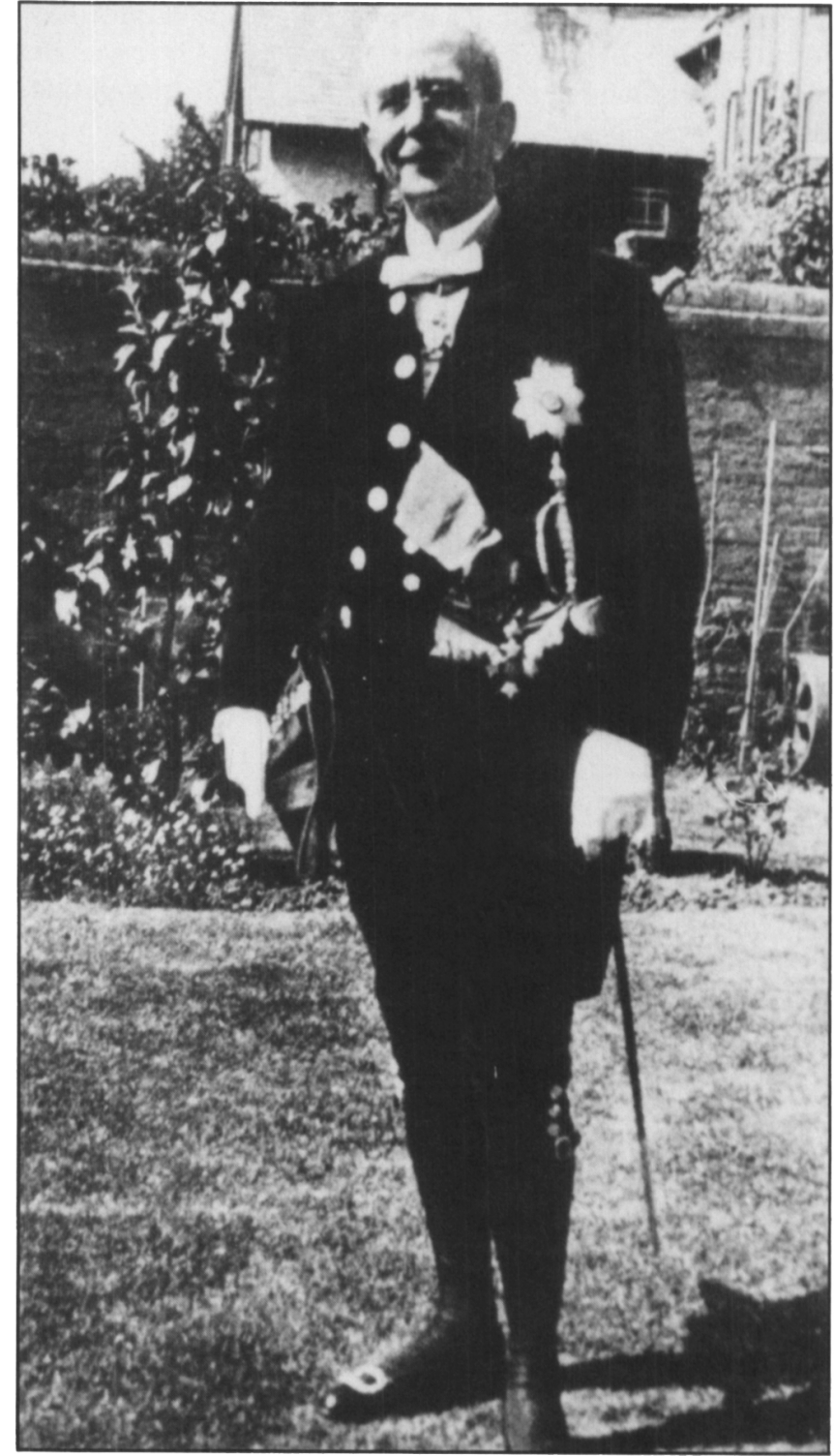

Figure 3 - Sherrington in 1922 in formal court dress and sword as Presidemt of the Royal Society.

before. I should add that in the machine-shop at the end of the day they rehearsed their dance band - after the professor had left, of course.

An eloquent description of Sherrington's work has been written by Professor Liddell in his volume: "The Discovery of Reflexes" and in his Royal Society obituary notice. Perhaps 1 may conclude with a reference to the extension of Sherrington's influence across the world. His ideas on the central excitatory state and on the central inhibitory state were incorporated into most textbooks of physiology and pharmacologists focussed on the synaptic area between neurones in a chain. John Fulton became Sterling professor of physiology at Yale and vigorously applied his Oxford ideas to the frontal lobes. Alas, he was not to share in the Nobel prize given for clinical applications of his fine work. Eccles took the Sherrington fire to Australia and New Zealand, earning a highly merited Nobel Prize. Granit returned to Stockholm and became a Nobel laureate. Howard Florey gave the world therapeutic penicillin from his superb laboratory a hundred yards along South Parks Road from 
Sherrington's laboratory. Thus Sherrington produced three Nobelists. His own Nobel prize, awarded in 1932, was the result of the submissions of 134 persons over a 30 -year period. He had to wait, however, until his opponent on the committee died; then Sherrington shared it with Adrian of Cambridge, one of his greatest admirers. While Sherrington was receiving the prize in Stockholm, Wilder Penfield was trying to compress the plans drawn for the Montreal Neurological Institute at McGill to conform to the money available. The Great Depression was at its worst but Penfield, having come from the Presbyterian Hospital in New York was determined to integrate basic and clinical research in the nervous system with exemplary care of neurological and neurosurgical patients.

The Rockefeller Foundation, through its remarkable emissary, Alan Gregg, once a Harvard researcher with Sherrington's pupil Alex Forbes - gave McGill University, in 1932, one million dollars as an endowment for the Montreal Neurological Institute's research and training work, and $\$ 232,6 \$ 2$ for the construction of its buildings, the latter sum to be matched by local philanthropy.

As the most junior of the assembled researchers at the opening of the M.N.I. in September of $1934 \mathrm{I}$ can attest to the fact that the air was electric with anticipation. Sherrington's two pupils, Penfield and Cushing dominated the scene, the former able to produce the kind of institution which the latter had tried to organize at the end of World War I.

Within a short time the neuro-sciences began their swift ascent at McGill with the coming of Herbert Jasper in electroencephalography and of Donald Hebb in neuro-psychological exploration of frontal lobe activity in humans. The early EEG studies were made by Dr. Jasper on week-ends as he bundled his equipment into his Studebaker car at Providence, Rhode Island, and drove through rain and snow storms to far-off Montreal. The customs officers at the border became accustomed to this perfectly bilingual mystery man and imagined, no doubt, that he was a radio announcer on his way to broadcast a Montreal football or hockey game to American audiences.

The application of the early EEG techniques is said to have begun with Hans Berger in 1925, but the fact is that Sherrington's pupil, Alexander Forbes at Harvard, was recording from the brain several years earlier. He was persuaded to give up this supposed nonsense in order to save his reputation! The great advance which Herbert Jasper in the mid-thirties ushered in could only have been achieved in one place of which I know and that was Montreal. There neurosurgery by Wilder Penfield offered hope to a select group of epileptics, based on stimulation and thus localization of activity on the exposed brain in conscious patients who had the benefit of excellent local anaesthesia. Upon this fascinating operative scene Dr. Jasper was able to superimpose cortical recordings during brain operations in patients who had already had intensive EEG studies through the intact cranium.

As I can testify these were long and arduous sessions, and I still marvel at the fortitude and co-operative spirit of the patients. They, however, were intimately aware that what was being studied upon their "unroofed" brain would help them and others like them for generations to come.

Thus the localization of cerebral function, adumbrated so long ago by Hippocrates, Ferrier, Hughlings Jackson, Sherrington, Cushing and others was now being pinned down in physiological terms, far beyond the wildest dreams of histologists such as Ramón y Cajal, Brodmann, the Vogts, Alfred Campbell and von Bonin.

The "Sherrington Era" had not come to its end with the opening of the Montreal Neurological Institute - far from it but the integrative action achieved by Wilder Penfield, under one roof, between students of the form and function of the CNS was a milestone indeed. The neuropathological studies under the direction of William Vernon Cone and the physiological recordings and interpretations of the Jasper team - and a large one it became - set a standard of excellence that pleased both Sherrington and his admirer Alan Gregg - the wise man of the Rockefeller Foundation.

Perhaps I might conclude by reciting to you, briefly, the substance of a conversation between Gregg and Sherrington at Oxford. Gregg asked what was Oxford's role in the world; Sherrington replied:

"After some hundreds of years of experience we think we have learned here in Oxford how to teach what is known. But now with the undeniable upsurge of scientific research, we cannot continue to rely on the mere fact that we have learned how to teach what is known. We must learn how to teach the best attitude to what is not yet known. This also may take centuries to acquire but we cannot escape this new challenge, nor do we want to."

I think that neuroscientists will agree with Sherringtonians such as Herbert Jasper that "we cannot escape this new challenge, nor do we want to." 